\title{
Methylmercury in Industrial Harbor Sediments in Taiwan: First Observations on Its Occurrence, Distribution, and Measurement
}

\author{
Chih-Feng Chen, Yun-Ru Ju, Guan-Ting Lin, Chiu-Wen Chen * and Cheng-Di Dong * \\ Department of Marine Environmental Engineering, National Kaohsiung University of Science and Technology, \\ Kaohsiung 81157, Taiwan; dong3762@nkust.edu.tw (C.-F.C.); yrju@nkust.edu.tw (Y.-R.J.); \\ plxar1001@gmail.com (G.-T.L.) \\ * Correspondence: cwchen@nkust.edu.tw (C.-W.C.); cddong@webmail.nkmu.edu.tw (C.-D.C.); \\ Tel.: +886-7-365-0548 (C.-D.C.)
}

Received: 2 August 2018; Accepted: 15 August 2018; Published: 16 August 2018

\begin{abstract}
The distribution of methylmercury (MeHg) and total mercury (T-Hg) in sediments of the estuaries and the basin in Kaohsiung Harbor (Taiwan) is studied. MeHg in the sediment samples was determined using gas chromatography-mass spectrometry. The certified reference material of sediments with respect to the method showed the recovery efficiency between 97.4 and $103.6 \%$ which confirmed the applicability of analysis method. The T-Hg and MeHg concentrations were between 149 to $9035 \mu \mathrm{g} / \mathrm{kg}$ and $<0.31$ to $17.7 \mu \mathrm{g} / \mathrm{kg}$, respectively. The T- $\mathrm{Hg}$ and $\mathrm{MeHg}$ concentrations in the estuaries of Kaohsiung Harbor were relatively high. Results suggest that $\mathrm{Hg}$ in this studied area was likely contributed from the catchments of the rivers. The MeHg level was $<0.01$ to $2.66 \%$ of the T-Hg in the sediments. A positive correlation is obtained between $\mathrm{MeHg}$, $\mathrm{T}-\mathrm{Hg}$, and total organic carbon in the sediments, whereas a negative correlation is observed between $\mathrm{pH}$, oxidation-reduction potential, and $\mathrm{MeHg}$ concentration. The results further suggest that sediment characteristics contribute mainly to the distribution of $\mathrm{MeHg}$.
\end{abstract}

Keywords: mercury; methylmercury; estuary; sediments; MeHg; T-Hg; Kaohsiung

\section{Introduction}

The presence of mercury $(\mathrm{Hg})$ and methylmercury $(\mathrm{MeHg})$ in the environment is a major ecological risk due to their extreme toxicity and highly bio-accumulative properties. Some of the major sources of these materials are anthropogenic, which include agriculture, mining, incineration and municipal wastewater [1]. Due to its low solubility in receiving waters, $\mathrm{Hg}$ is easily adsorbed on the water-borne suspended particles. The particle-bound $\mathrm{Hg}$ finally accumulates in the sediments. Mercury in sediments is generally in bivalent form complexed with chlorides, sulfides or organic matter [2]. The inorganic bivalent $\mathrm{Hg}$ may be transformed into $\mathrm{MeHg}$ via the biochemical actions of local microorganisms, such as sulfate-reducing bacteria (SRB), Fe(III)-reducing bacteria, and methanogenic microorganisms [3-7]. MeHg can bind to proteins and pass through the biological membrane, enabling its accumulation in the food web and biomagnification, which ultimately threatens the health of wildlife and human [2,8]. Sediments are the important niche and matrix for fishes and aquatic invertebrates, hence understanding the distribution of $\mathrm{MeHg}$ in aquatic sediments is necessary.

Mercury methylation occurs mainly in aquatic sediments [9]. The bioavailability of inorganic bivalent $\mathrm{Hg}$ in the sediments and the microbial methylation and demethylation activities are the most critical factors determining the $\mathrm{MeHg}$ level in the sediment. Additionally, environmental conditions such as sulfur, organic matter, iron, temperature, $\mathrm{pH}$, redox conditions, and salinity also play important roles in mercury methylation [10]. Under anaerobic conditions, the increase in organic matter and 
sulfur content are beneficial in promoting microbial activity. The bioavailability of inorganic bivalent $\mathrm{Hg}$ also promotes $\mathrm{Hg}$ methylation. However, a high sulfur content may hasten formation of $\mathrm{Hg}$ sulfide precipitates (e.g., $\mathrm{HgS}(\mathrm{s})$ ), which in turn decreases the bioavailable $\mathrm{Hg}$ in the sediments and inhibits $\mathrm{Hg}$ methylation [2]. Therefore, environmental conditions and sediment characteristics result in variations in the distribution of $\mathrm{MeHg}$ in the sediments [11,12].

According to the available literature with regards to total Hg-related studies, there are few field studies on $\mathrm{MeHg}$ distribution in sediments. Generally, the main steps of $\mathrm{MeHg}$ analysis procedures for solid samples are alkaline digestion (or acid leaching), tetraethylborate derivatization for reducing the polarity of target chemical, solvent extraction by heptane, benzene, toluene, dichloromethane, or hexane, chromatographic separation by gas chromatography (GC) or high performance liquid chromatography (HPLC), and detection by mass spectrometry (MS), electron capture detector (ECD), inductively coupled plasma mass spectrometry (ICP-MS), or cold vapour atomic fluorescence spectroscopy (CVAFS) [9,12-14]. This study analyzes MeHg content in sediments based on the above procedures and carried out qualitative and quantitative analyses to confirm the accuracy of the analytical results.

Kaohsiung Harbor is located at the southwest coast of Taiwan. Heavy industries around this area highly depend on it due to its important role as an intercontinental container hub in logistic operations. The estuaries of Love River, Canon River, Jen-Gen River, and Salt River lie along the Kaohsiung Harbor. These four rivers are known to be contaminated with municipal sewage and industrial wastewater. Previous research indicated that the sediments in Kaohsiung Harbor were heavily polluted with $\mathrm{Hg}(0.06-6.73 \mathrm{mg} / \mathrm{kg})$, suggesting that the main pollution sources may be these four rivers, especially the Love River and Canon River [15]. However, the distribution of the $\mathrm{MeHg}$ concentration in Kaohsiung Harbor and its correlation with the sediment characteristics have not been investigated. Thus, this study attempts to build a routine $\mathrm{MeHg}$ analysis procedure for the sediments collected from the estuary and the harbor of Kaohsiung Harbor, to understand the distribution, and pollution levels of $\mathrm{Hg}$ and $\mathrm{MeHg}$ in their sediments, and to investigate the major factors affecting the distribution of $\mathrm{MeHg}$ in the sediments by correlation analysis.

\section{Materials and Methods}

\subsection{Sediment Collection and Analysis}

Twenty stations were set up in in four estuaries (4: Love River, 6: Canon River, 10: Jen-Gen River, and 18: Salt River), two entrances (1: Entrance I and 19, 20: Entrance II), and navigation channels (2, 3, 5, 7, 8, and 9: the north navigation channel and 11-17: the south navigation channel) of Kaohsiung Harbor to collect the surface sediment samples $(0-15 \mathrm{~cm})$ using an Ekman Dredge Grab (Figure 1). The sampled sediment was put into an amber glass bottle that has been $n$-hexane washed, and held in an icebox filled with ice. When the sediment samples arrived in the laboratory, they were freeze-dried for 3 days, ground, and filtered through a $1.0 \mathrm{~mm}$ sieve to make them completely homogeneous.

A Coulter LS Particle Size Analyzer (Beckman Coulter, Inc., Brea, CA, USA) was used to analyze the particle size of sediment sample. Total organic carbon (TOC) was measured using the Walkley-Black method, which involves titration with ferrous ammonium sulfate of the dichromate remaining after a wet combustion of the sample with potassium dichromate $[16,17]$. The $\mathrm{pH}$ of sediment was determined by the electrode method. Sediment was mixed with water in a 1:1 ratio and continuously stirred for $5 \mathrm{~min}$. Rested the mixture stand for $1 \mathrm{~h}$ and used the $\mathrm{pH}$ meter to measure the $\mathrm{pH}$ of the upper layer of water in the mixture [18]. ORP (oxidation-reduction potential) value in sediment was measured by redox meter immediately after sampling [19]. Briefly, a microwave digester (CEM MARS 6, Matthews, $\mathrm{NC}$, USA) was used to digest $0.5 \mathrm{~g}$ dry sediment samples, which had been mixed with a mixture of ultra-pure acids $\left(\mathrm{HNO}_{3}: \mathrm{HCl}: \mathrm{HF}=9: 3: 3\right)$. The digested solution was filtered through $0.45 \mu \mathrm{m}$ filter paper; the filtrate was diluted with ultra-pure water to a certain volume. Total mercury (T-Hg) content 
in sediments was determined using a cold vapor atomic absorption spectrophotometer (CVAAS) (Hitachi FHS-2 and Hitachi Z-6100, Tokyo, Japan), according to the procedure of Dong et al. [15].

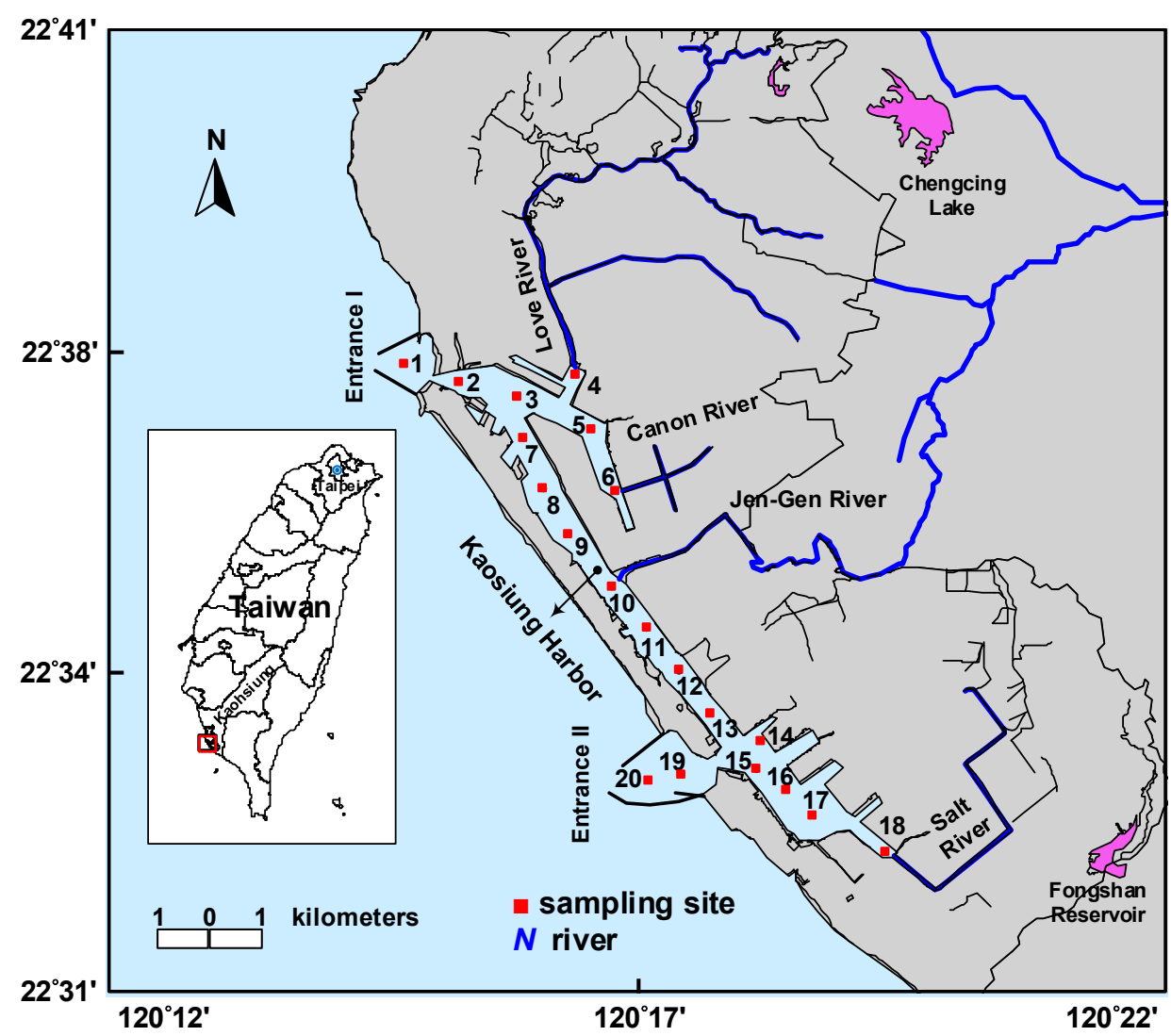

Figure 1. Map of the study area and location of the sampling stations.

\subsection{Methylmercury Analysis in Sediment}

\subsubsection{Chemicals and Reagents}

All solvents and reagents used were of trace analysis (TA), chromatographic (HPLC) or American Chemical Society (ACS) grade. Methyl mercury chloride ( $\mathrm{MeHgCl}, 95 \%$ purity), tetramethylammonium hydroxide (TMAH, $25 \%$ in water), and sodium tetraethylborate ( $\mathrm{NaBEt}_{4}$, 99.8\% purity) were all purchased from Merck (Darmstadt, Germany), while cupric acetate monohydrate $\left(\mathrm{Cu}\left(\mathrm{CO}_{2} \mathrm{CH}_{3}\right) 2 \mathrm{H}_{2} \mathrm{O}, 95 \%\right.$ purity) and potassium hydroxide $(\mathrm{KOH}, 87 \%$ purity) were both obtained from Osaka Chemical Co., Ltd. (Osaka, Japan). Acetic acid $\left(\mathrm{CH}_{3} \mathrm{COOH}, 99.8 \%\right.$ purity), sodium acetate anhydrous $\left(\mathrm{C}_{2} \mathrm{H}_{3} \mathrm{NaO}_{2}, 98 \%\right.$ purity), methanol $\left(\mathrm{CH}_{3} \mathrm{OH}, 99 \%\right.$ purity), and $n$-heptane (99\% purity) were acquired from Scharlau (Barcelona, Spain), Showa Chemical Industry Co., Ltd. (Tokyo, Japan), Macron Fine Chemicals ${ }^{\mathrm{TM}}$ (Center Valley, PA, USA), and ACROS (Geel, Belgium), respectively. Ultra-pure water $(>18 \mathrm{M} \Omega \cdot \mathrm{cm})$ from a Barnstead Water Purification System (Thermo Fisher Scientific, Waltham, MA, USA) was used throughout in this study.

The stock standard solution of $\mathrm{MeHgCl}(1000 \mathrm{mg} / \mathrm{L})$ was prepared by dissolving $\mathrm{MeHgCl}$ in methanol. An intermediate standard solution of $\mathrm{MeHgCl}(10 \mathrm{mg} / \mathrm{L})$ was prepared by diluting the stock standard solution with methanol. A series of calibration standard solution was prepared weekly by diluting the intermediate standard solution with ultrapure water to a range of 2.5-60 pg. All of the standard solutions were placed at $4{ }^{\circ} \mathrm{C}$ in amber glass bottles pre-washed with n-hexane and sealed with the Teflon-lined cap. The derivatization solution, i.e., $1 \% \mathrm{NaBEt}_{4}$ solution, was prepared by dissolving $1 \mathrm{~g} \mathrm{NaBEt}_{4}$ in $100 \mathrm{~mL}$ of $2 \%$ potassium hydroxide solution. The solution was divided 
into several $20 \mathrm{~mL}$ vials and stored at a $-20^{\circ} \mathrm{C}$ freezer (up to 1 month). A buffer solution $(1 \mathrm{M})$ at $\mathrm{pH} 5.0$ was prepared by mixing sodium acetate anhydrous and acetic acid in water. Copper solution $(0.4 \mathrm{mM})$ was prepared by dissolving cupric acetate monohydrate in water.

\subsection{2. $\mathrm{MeHg}$ Analytical Procedure}

Two grams (accuracy $\pm 0.0001 \mathrm{~g}$ ) of dry and homogenized sediment sample was put in a clean centrifuge tube (with Teflon-lined cap), and a $5 \mathrm{~mL}$ TMAH solution was added. Blanks were prepared following the same procedure without adding sediment sample. The standard sample used for quality control was prepared by adding the standard solution to TMAH solution. All samples were vortexed for $1 \mathrm{~min}$ and the mixture was subject to ultrasonic treatment using a bath sonicator (output power $200 \mathrm{~W}$; frequency $40 \mathrm{KHz}$ ) that was filled with ice and water in $\sim 15^{\circ} \mathrm{C}$ for $15 \mathrm{~min}$. The samples were neutralized by acetic acid and $1 \mathrm{~mL}$ of $20 \mathrm{mM}$ copper solution, $5 \mathrm{~mL}$ of $1 \mathrm{M}$ acetate buffer $(\mathrm{pH}=5.0)$ and $1 \mathrm{~mL}$ of $1 \% \mathrm{NaBEt}_{4}$ solution were then added. The mixture was vortexed and subjected to ultrasonic treatment. Then, $1 \mathrm{~mL}$ of $\mathrm{n}$-heptane was added and the resulting mixture was again vortexed and subjected to ultrasonic treatment. The sample tubes were then centrifuged at $1500 \times g$ for $10 \mathrm{~min}$. After centrifugation, the organic layer containing the target compounds was drawn with a Pasteur pipette and the extract was analyzed using gas chromatography with mass selective detection (GC-MS).

\subsubsection{GC-MS Instrumentation and Conditions}

A GC-MS system that included an Agilent 7683B Injector, an Agilent 7890N GC, an Agilent 5975 mass selective detector (MSD) (Agilent Technologies, Santa Clara, CA, USA) and a capillary column (HP-5MS, $30 \mathrm{~m}, 0.25 \mathrm{~mm}$ id, and film thickness $0.25 \mu \mathrm{m}$ ) (Hewlett-Packard, Palo Alto, CA, USA) was used to separate and quantify MeHg in the sediment samples. One $\mu \mathrm{L}$ of sample was injected in splitless mode at an injection temperature of $260^{\circ} \mathrm{C}$. The transfer line and ion source temperature were at $280{ }^{\circ} \mathrm{C}$ and $230{ }^{\circ} \mathrm{C}$, respectively. The column temperature was initially held at $45^{\circ} \mathrm{C}$ for $10 \mathrm{~min}$, raised to $280^{\circ} \mathrm{C}$ at the rate of $20^{\circ} \mathrm{C} / \mathrm{min}$, and finally held constant for $10 \mathrm{~min}$. Detector temperature was designed $280^{\circ} \mathrm{C}$. The carrier gas of Helium was at a constant flow rate of $1 \mathrm{~mL} / \mathrm{min}$. Mass spectrum was acquired using electron ionization (EI) and selective ion monitoring (SIM) modes. The ions set to scan were 202, 217, 231, and $246 \mathrm{~m} / \mathrm{z}$ for MeHg.

\subsubsection{Identification and Quantification of $\mathrm{MeHg}$}

Qualitative analysis of $\mathrm{MeHg}$ was conducted based on the above conditions. $\mathrm{MeHg}$ standard was analyzed under scan mode (scan range: 50-500 amu; scan rate: 1.6 times per sec). By comparing with the mass spectrometry database (National Institute of Standards and Technology, NIST, Gaithersburg, MA, USA), the retention time and major ions of $\mathrm{MeHg}$ could be defined. $\mathrm{MeHg}$ in the sample was qualitatively analyzed according to the retention time and the major/minor quantitative ion intensity of the authentic MeHg standards. Quantitative analysis was conducted according to the average calibration factors (CF) based on the six-point calibration curve of $\mathrm{MeHg}$. The $\mathrm{CF}$ was calculated by dividing the peak area of major ion $(217 \mathrm{~m} / \mathrm{z})$ and minor ion $(246 \mathrm{~m} / \mathrm{z})$ by the concentration of $\mathrm{MeHg}$. In this study, the concentration of $\mathrm{MeHg}$ is expressed in unit of microgram per kilogram dry-weight sediment $(\mu \mathrm{g} / \mathrm{kg} \mathrm{dw})$.

\subsection{Data Analysis}

Statistical methods (i.e., mean, standard deviation, maximum, and minimum) were used in data analysis. The concentration distribution diagram of $\mathrm{MeHg}$ and $\mathrm{T}-\mathrm{Hg}$ were sketched with Surfer ${ }^{\circledR}$ Version 8.0 software (Golden Software Inc., Golden, CO, USA, 2002). The correlation among all the sediment characteristics (e.g., grain size, $\mathrm{pH}, \mathrm{ORP}$, and TOC) and $\mathrm{Hg}$ concentrations (MeHg and T-Hg) determined by the Pearson correlation coefficient using the statistics software SPSS 12.0. 


\section{Results and Discussion}

\subsection{Quality Assurance and Quality Control (QAQC) for Methylmercury Analysis}

The six-point calibration curve (2.5 to $60 \mathrm{pg}$ ), procedural blank, check standard, and sample duplicates were carried out for each set of samples. The calibration factor based on the six-point calibration curve for MeHg showed acceptable relative standard deviation (RSD) values (4.1\%). All of procedural blank values were lower than the detection limit. The recovery of $\mathrm{MeHg}$ in check standards ranged from 82.3 to $101.1 \%(n=6)$, and the relative percent difference of sample duplicates ranged from 4.0 to $8.6 \%(n=4)$ for the analyses of $\mathrm{MeHg}$ (Table 1). The detection limit of the analytical procedure was estimated from three times standard deviation from repeated $(n=7)$ analysis of $\mathrm{MeHg}$ (2.5 pg), and the amount of sample extracted. The detection limit of MeHg was $0.31 \mu \mathrm{g} / \mathrm{kg} \mathrm{dw}$ (Table 1). The reference material ERM-CC580 (estuarine sediment) from Institute for Reference Materials and Measurements (IRMM), European Commission-Directorate General Joint Research Centre (Geel, Belgium) was used. Table 2 shows certified and measured concentrations. There is a good agreement between certified and measured results and the recovery was between $97.4 \%$ and $103.6 \%$ for $\mathrm{MeHg}$.

Table 1. Calibration factor, detection limits, recoveries of check standards, and relative percent differences of sample duplicates for $\mathrm{MeHg}$ analysis.

\begin{tabular}{|c|c|c|c|c|c|}
\hline \multicolumn{2}{|c|}{$\begin{array}{l}\text { Calibration Factor (CF) } \\
\qquad(n=6)\end{array}$} & \multirow{2}{*}{$\begin{array}{l}\text { Detection Limits } \\
\quad(\mu \mathrm{g} / \mathrm{kg} \mathrm{dw})\end{array}$} & \multirow{2}{*}{$\begin{array}{c}\text { Blank Analysis } \\
(\mathrm{n}=6) \\
(\mu \mathrm{g} / \mathrm{kg} \mathrm{dw})\end{array}$} & \multirow{2}{*}{$\begin{array}{l}\text { Check Analysis } \\
(\mathrm{n}=6) \\
\mathrm{R}^{1}(\%)\end{array}$} & \multirow{2}{*}{$\begin{array}{c}\text { Duplication Analysis } \\
(\mathrm{n}=4) \\
\operatorname{RPD}^{1}(\%)\end{array}$} \\
\hline Average \pm SD $^{1}$ & $\operatorname{RSD}^{1}(\%)$ & & & & \\
\hline $2513 \pm 103$ & 4.1 & 0.31 & $<\mathrm{DL}$ & $91.8 \pm 6.9$ & $6.2 \pm 2.4$ \\
\hline
\end{tabular}

Table 2. Analysis of methylmercury from reference materials ERM-CC580 (estuarine sediment).

\begin{tabular}{|c|c|c|c|c|c|}
\hline \multirow{2}{*}{ Compounds } & \multicolumn{4}{|c|}{ Measured Value ( $\mu \mathrm{g} / \mathrm{kg} \mathrm{dw})$} & \multirow{2}{*}{$\begin{array}{l}\text { Certified Value } \\
(\text { mean } \pm \text { SD) }\end{array}$} \\
\hline & $\# 1$ & $\# 2$ & $\# 3$ & Mean \pm SD $^{1}$ & \\
\hline $\mathrm{MeHg}$ & 77.2 & 72.6 & 73.8 & $74.5 \pm 2.4$ & $75.5 \pm 4.8$ \\
\hline
\end{tabular}

\subsection{GC-MS Separation and Identification}

Prior to analyzing the sediment samples, the efficiency of GC-MS for analyzing MeHg concentration was tested with a $\mathrm{MeHgCl}$ standard solution. The $\mathrm{MeHgCl}$ standard solution was derivatized by $\mathrm{NaBEt}_{4}$, extracted by $n$-heptane, followed by GC-MS analysis in scan mode. The retention time of the $\mathrm{MeHgEt}$, the derivative of $\mathrm{MeHgCl}$ standard, was $4.612 \mathrm{~min}$. Figure 2A shows the mass spectra of MeHgEt, the derivative of $\mathrm{MeHgCl}$. The major ion was $217 \mathrm{~m} / \mathrm{z}$, and the minor ions included 202, 231, and $246 \mathrm{~m} / \mathrm{z}$. The identity of $\mathrm{MeHg}$ was confirmed by the retention time and abundance of quantification ions in the authentic MeHg standards. The separation and quantitation of $\mathrm{MeHg}$ in the sediment samples were achieved using the same GC-MS conditions as the standards. The MeHg was quantified using the calibration factor based on the six-point calibration curve. Figure 2B-H shows the sample chromatogram of the selected major ion $217 \mathrm{~m} / \mathrm{z}$ for the check standard, reference material (ERM-CC580), procedural blank, and four estuaries. The peak of $\mathrm{MeHg}$ for all samples was clearly separated without noise interfering at the retention time of $4.61 \mathrm{~min}$.

\subsection{Sediment Characteristics}

Table 3 lists the distributions of sediment characteristics of the 20 stations, including grain size, TOC, ORP, and $\mathrm{pH}$. The dominate composition of grain size in sediments collected from the studied area was the fine particle (clay and silt, $<63 \mu \mathrm{m}$ ), accounting for 55.1-90.4\%, except for stations 1, 2, 6, 7,11 , and 15 which were dominated by sand $(>63 \mu \mathrm{m})$ with about $57.8-100 \%$. The higher TOC content 
was found in the sediments of estuaries with $1.72-2.50 \%$, whereas the relatively lower one $(0.71-1.63 \%)$ was found in the remaining stations, including channels and entrances (Figure 3A). On the contrary to the distribution of TOC, $\mathrm{pH}$ values in the sediments of estuary stations ( $\mathrm{pH}$ : 7.31-7.52) were relatively lower than those in the remaining stations (pH: 7.31-7.81) (Table 3).
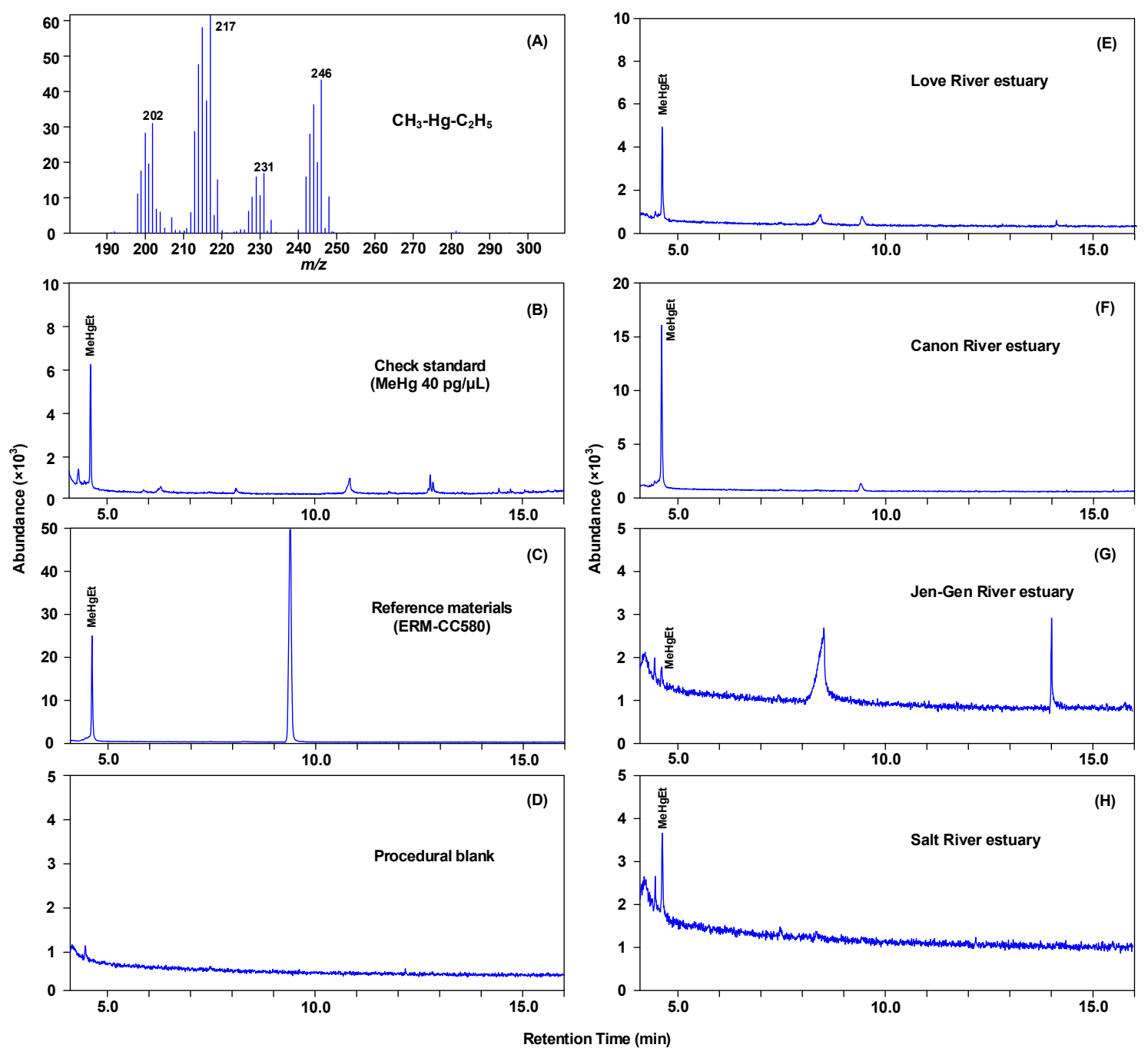

Figure 2. (A) The electron impact mass spectra for GCMS analysis of $\mathrm{MeHgCl}$ standard solution derivatizing with NaBEt4; chromatogram of the selected major ion $217 \mathrm{~m} / \mathrm{z}$ for (B) the check standard, (C) reference material (ERM-CC580), (D) procedural blank, and four estuaries of (E) Love River, (F) Canon River, (G) Jen-Gen River, and (H) Salt River.

Negative ORP values were measured in all sampling stations $(-129--392 \mathrm{mV})$ especially the estuary stations with high TOC content (ORP: $-254--392 \mathrm{mV}$ ) (Figure 3B). This indicates that the sediments of Kaohsiung Harbor are in anaerobic state, which can be attributed to the microbial mediated oxidation of the organic matter consuming oxygen in the sediments. The lower $\mathrm{pH}$ value and higher TOC content were found in the sediment of estuary stations because these stations receive the inputs from freshwater of rivers and terrigenous organic matter. The higher TOC content was associated with the reducing state of the sediment. 
Table 3. The basic characteristics, total mercury (T-Hg), and methylmercury ( $\mathrm{MeHg}$ ) in sediment samples collected from the estuarine and channel of Kaohsiung Harbor.

\begin{tabular}{cccccccccc}
\hline Site & $\begin{array}{c}\text { Clay } \\
(\mathbf{\%})\end{array}$ & $\begin{array}{c}\text { Silt } \\
\mathbf{( \% )}\end{array}$ & $\begin{array}{c}\text { Sand } \\
\mathbf{( \% )}\end{array}$ & $\begin{array}{c}\text { TOC } \\
\mathbf{( \% )}\end{array}$ & $\mathbf{p H}$ & $\begin{array}{c}\text { ORP } \\
(\mathbf{m V})\end{array}$ & $\begin{array}{c}\text { T-Hg } \\
(\boldsymbol{\mu g} / \mathbf{k g})\end{array}$ & $\begin{array}{c}\mathbf{M e H g} \\
(\boldsymbol{\mu g} / \mathbf{k g})\end{array}$ & $\begin{array}{c}\mathbf{M e H g ~ R a t i o ~}^{\mathbf{1}} \\
\mathbf{( \% )}\end{array}$ \\
\hline 1 & $<0.01$ & $<0.01$ & 100.0 & 0.92 & 7.77 & -146 & 401 & 0.61 & 0.14 \\
2 & 4.3 & 37.9 & 57.8 & 0.86 & 7.55 & -143 & 702 & 2.49 & 0.33 \\
3 & 7.5 & 82.9 & 9.6 & 1.33 & 7.31 & -129 & 1699 & 2.55 & 0.14 \\
4 & 4.2 & 51.7 & 44.1 & 2.50 & 7.32 & -392 & 1988 & 6.81 & 0.32 \\
5 & 6.2 & 72.9 & 20.9 & 1.63 & 7.40 & -245 & 1944 & $<0.31$ & 0.01 \\
6 & 2.3 & 16.2 & 81.5 & 2.39 & 7.31 & -385 & 9035 & 17.67 & 0.18 \\
7 & 2.2 & 14.3 & 83.5 & 1.53 & 7.50 & -286 & 472 & 4.94 & 0.97 \\
8 & 7.6 & 60.3 & 32.1 & 1.31 & 7.61 & -252 & 298 & 2.20 & 0.69 \\
9 & 7.7 & 79.0 & 13.3 & 1.36 & 7.45 & -215 & 297 & 1.99 & 0.62 \\
10 & 7.1 & 71.2 & 21.8 & 1.72 & 7.43 & -254 & 896 & 2.02 & 0.21 \\
11 & 4.0 & 35.8 & 60.2 & 1.47 & 7.45 & -222 & 149 & 4.26 & 2.66 \\
12 & 5.4 & 49.8 & 44.8 & 1.17 & 7.78 & -199 & 374 & 2.33 & 0.58 \\
13 & 5.5 & 52.1 & 42.4 & 1.52 & 7.74 & -158 & 646 & 1.75 & 0.25 \\
14 & 8.2 & 69.2 & 22.6 & 1.02 & 7.81 & -220 & 521 & 1.58 & 0.28 \\
15 & 4.9 & 33.5 & 61.6 & 0.91 & 7.70 & -157 & 223 & $<0.31$ & 0.06 \\
16 & 7.4 & 66.9 & 25.8 & 0.71 & 7.58 & -231 & 447 & $<0.31$ & 0.03 \\
17 & 7.6 & 69.3 & 23.1 & 1.17 & 7.49 & -193 & 449 & $<0.31$ & 0.03 \\
18 & 6.6 & 68.1 & 25.3 & 2.84 & 7.52 & -338 & 524 & 4.19 & 0.75 \\
19 & 6.4 & 48.7 & 45.0 & 1.01 & 7.65 & -179 & 199 & $<0.31$ & 0.07 \\
20 & 6.9 & 61.2 & 31.8 & 1.07 & 7.64 & -174 & 173 & $<0.31$ & 0.08 \\
\hline
\end{tabular}

${ }^{1} \mathrm{MeHg}$ ratio $=\mathrm{T}-\mathrm{Hg} / \mathrm{MeHg}$ as $\mathrm{Hg}$; using $1 / 2 \mathrm{DL}$ as the calculating concentration when the concentration of $\mathrm{MeHg}$ was below to DL.
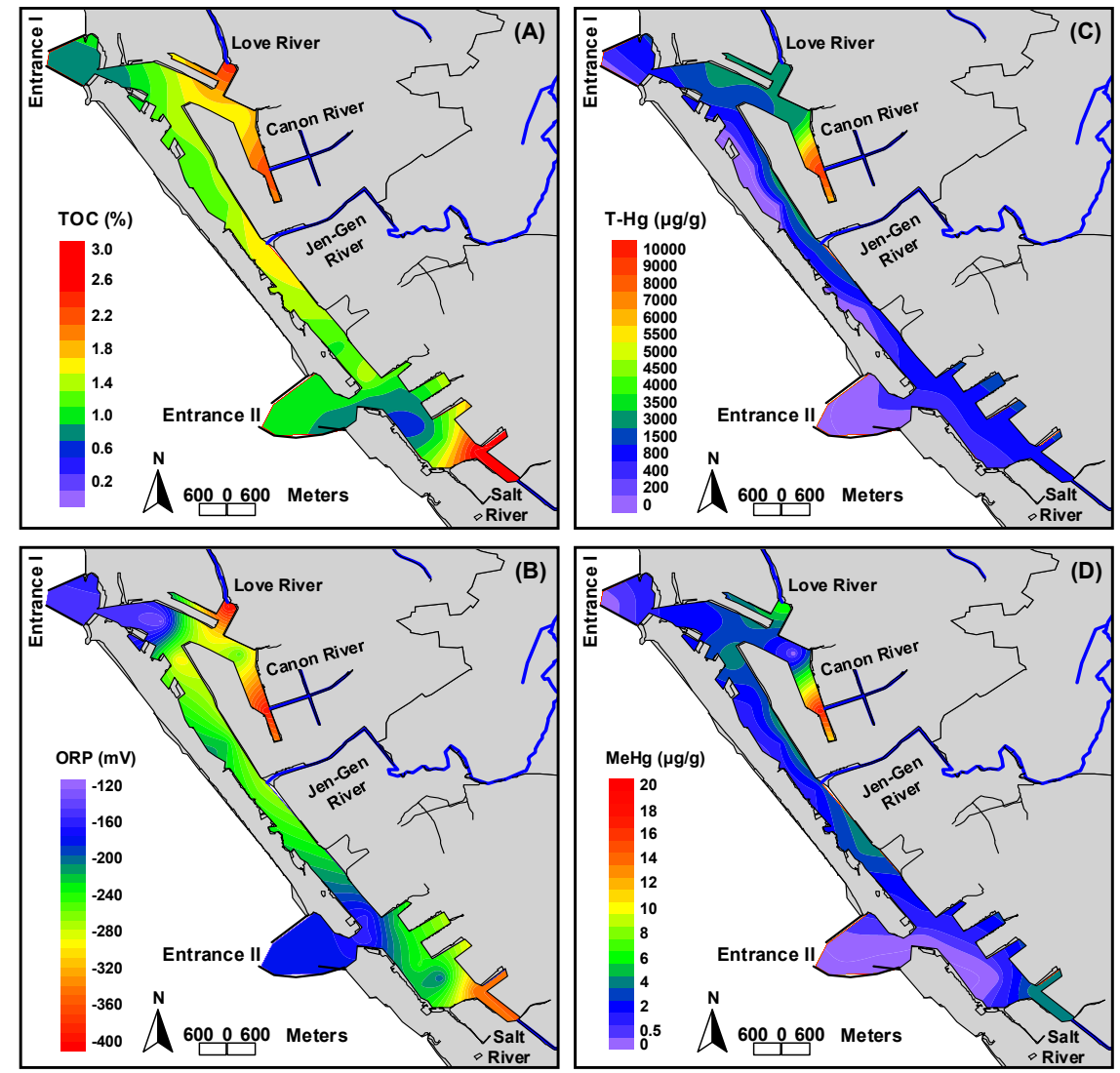

Figure 3. The distributions of (A) TOC content, (B) ORP, (C) T-Hg, and (D) MeHg concentrations in the sediments of Kaohsiung Harbor. 


\subsection{Distribution of Total Mercury and Methylmercury in Sediments}

The T-Hg concentrations ranged from 149 to $9035 \mu \mathrm{g} / \mathrm{kg}$ with mean \pm SD of $1072 \pm 1957 \mu \mathrm{g} / \mathrm{kg}$ in all 20 sampling stations. The higher T-Hg concentrations were found at the area around station 3 to station $6(1699-9035 \mu \mathrm{g} / \mathrm{kg})$, especially for station 6 which presented a high T-Hg concentration of $9035 \mu \mathrm{g} / \mathrm{kg}$; whereas the remaining stations showed T-Hg concentrations lower than $1000 \mu \mathrm{g} / \mathrm{kg}$ $(149-896 \mu \mathrm{g} / \mathrm{kg}$ ) (Table 3). The T-Hg concentration measured in this study was comparable with the effect range low (ERL: $150 \mu \mathrm{g} / \mathrm{kg}$ ) and effect range median (ERM: $710 \mu \mathrm{g} / \mathrm{kg}$ ) published by the US National Oceanic and Atmospheric Administration [20]. All of the detected T-Hg concentrations in the sediment exceeded the ERL value of $150 \mu \mathrm{g} / \mathrm{kg}$. The T-Hg concentrations at stations 3, 4 (Love River estuary), 5, 6 (Canon River estuary), and 10 had also exceeded the ERM value of $710 \mu \mathrm{g} / \mathrm{kg}$, indicating that the levels of $\mathrm{T}-\mathrm{Hg}$ in the sediments may adversely impact the benthic organisms. Figure $3 \mathrm{C}$ illustrated the distribution of T-Hg concentrations in the sediments of Kaohsiung Harbor. It can be found that the major hot pollution zone was around the Canon River estuary (station 6). The T-Hg concentration progressively decreased toward the channel and the entrances. Result of the distribution of T-Hg clearly demonstrated that $\mathrm{Hg}$ accumulated in the sediments along the harbor area came from freshwater inputs. The main pollution sources may be municipal sewage and industrial wastewater discharges to the river upstream or along the river (e.g., metal processing, plastics, paint and dye, chemical manufacturing, electronics, motor vehicle plating and finishing, paper and board mills, and foundries) $[15,21]$.

$\mathrm{MeHg}$ concentration was detected in 14 of the 20 sediment samples collected from the studied area with the range between 0.61 and $17.7 \mu \mathrm{g} / \mathrm{kg}$. The highest $\mathrm{MeHg}$ concentrations were observed in station 4 (Love River, $6.81 \mu \mathrm{g} / \mathrm{kg}$ ) and 6 (Canon River, $17.7 \mu \mathrm{g} / \mathrm{kg}$ ) (Table 3). The spatial distribution pattern of MeHg in the sediment was similar to that of T-Hg, TOC content, and ORP (Figure 3). Previous studies had indicated that $\mathrm{MeHg}$ concentration in the sediment was associated with $\mathrm{T}-\mathrm{Hg}$ because $\mathrm{MeHg}$ in the sediments mainly was transferred by the bioavailable $\mathrm{Hg}$ via the biochemical effects [12,22]. Therefore, the sediments with the higher T-Hg concentration generally exhibited relatively higher MeHg concentration [12,23,24]. Moreover, the estuary sediments with high TOC content and the highly anaerobic state could promote the activity of microorganism, which favors $\mathrm{MeHg}$ formation resulting in relatively higher $\mathrm{MeHg}$ concentration in the above environment [2]. In this study, the sediments in the estuary stations had relatively higher level of $\mathrm{T}-\mathrm{Hg}, \mathrm{TOC}$ content, and redox state, especially for stations 4 (Love River estuary), 6 (Canon River estuary), and 18 (Salt River estuary); these stations exhibited the relatively higher MeHg concentration. Results showed the ratio of $\mathrm{MeHg}$ concentration to $\mathrm{T}-\mathrm{Hg}$ (MeHg ratio) ranged from $<0.01$ to 2.66, with the mean $\pm \mathrm{SD}$ of $0.42 \pm 0.60$. The MeHg ratio at stations 7-9, 11-12, and 18 (0.58-2.66) was relatively higher than that at other stations (0.01-0.32), indicating that the sediment at those stations contained a higher portion of bioavailable inorganic $\mathrm{Hg}$, thus resulting in a higher portion of $\mathrm{MeHg}$. Overall, the $\mathrm{MeHg}$ ratio of the sediment in Kaohsiung Harbor was similar to that in general estuary and marine about $<1.5 \%[9,25,26]$.

The concentrations of T-Hg and MeHg obtained in this study were compared with those available in the literature to understand the level of $\mathrm{Hg}$ pollution in Kaohsiung Harbor. As shown by the data listed in Table 4, the concentrations of T-Hg and $\mathrm{MeHg}$ in the sediments of Kaohsiung Harbor were slightly lower than that of the Gulf of Trieste and the Gulf of Taranto (Italy), Nerbion-lbaizabal Estuary (Spain), and Minamata Bay (Japan), but were relatively higher than other regions of the world. Additionally, $\mathrm{MeHg}$ ratio estimated in this studied was consistent with most of the other regions, lower than $1 \%$ (Table 4). Theoretically, the higher T-Hg concentration of sediments in Kaohsiung Harbor should provide the higher probability to produce $\mathrm{MeHg}$ but results were exactly the opposite. The phenomenon has been mentioned that high concentration of inorganic $\mathrm{Hg}$ may inhibit the methylation activity of microorganism and promote the demethylation, resulting in the $\mathrm{MeHg}$ ratio in sediments being limited in a certain range of $1 \%$ [26]. 
Table 4. Total mercury (T-Hg), methylmercury (MeHg), and the ratio of $\mathrm{MeHg}$ to $\mathrm{T}-\mathrm{Hg}$ (MeHg ratio) in the sediments of the different regions of the world.

\begin{tabular}{ccccc}
\hline Location & $\begin{array}{c}\mathbf{T}-\mathbf{H g} \\
(\boldsymbol{\mu g} / \mathbf{k g})\end{array}$ & $\begin{array}{c}\mathbf{M e H g} \\
(\boldsymbol{\mu g} / \mathbf{k g})\end{array}$ & $\begin{array}{c}\mathbf{M e H g} \text { Ratio } \\
\mathbf{( \% )}\end{array}$ & Reference \\
\hline Biscayne Bay, USA & 17 & 0.026 & 0.15 & {$[11]$} \\
Tampa Bay, USA & 8.3 & 0.049 & 0.59 & {$[11]$} \\
Charlotte Harbor, USA & 29 & 0.074 & 0.26 & {$[11]$} \\
Florida Bay, USA & 12 & 0.082 & 0.68 & {$[11]$} \\
Pine Island Sound, USA & 6.3 & 0.055 & 0.87 & {$[11]$} \\
Hudson river, USA & 1000 & 1.3 & 0.13 & {$[27]$} \\
San Francisco Bay, USA & 200 & 0.4 & 0.2 & {$[28]$} \\
Narragansett Bay, USA & 555 & 1.852 & 0.42 & {$[29]$} \\
Gulf of Trieste, Italy & 5240 & 16.9 & 0.32 & {$[30]$} \\
Gulf of Taranto, Italy & 2770 & 10.8 & 0.39 & {$[31]$} \\
Vistula Mouth, Poland & 71 & 0.354 & 0.50 & {$[23]$} \\
Odra mouth, Poland & 9 & 0.075 & 0.83 & {$[23]$} \\
Gulf of Gdansk, Poland & 164 & 0.645 & 0.39 & {$[32]$} \\
Anadyr Estuary, Russia & 339 & 0.254 & 0.22 & {$[32]$} \\
Mediterranean Basin & 110 & 1.33 & 1.21 & {$[33]$} \\
Nerbion-Ibaizabal Estuary, Spain & 2005 & 46.8 & 2.33 & {$[34]$} \\
Taheri Port, Iran & 34 & 0.2 & 0.69 & {$[35]$} \\
Dayyer Port, Iran & 26 & 0.2 & 0.65 & {$[35]$} \\
Persian Gulf, Iran & 20 & 0.14 & 0.71 & {$[36]$} \\
Dora, Lebanon & $100-650$ & $0.07-0.5$ & $0.03-0.35$ & {$[37]$} \\
Minamata Bay, Japan & 2960 & 1.74 & 0.06 & {$[24]$} \\
Isahaya Bay, Japan & 66 & 0.11 & 0.16 & {$[24]$} \\
Off Kuala Terengganu, Malaysia & 61 & 0.038 & 0.11 & {$[32]$} \\
Victoria Harbor, Hong Kong & 247 & $<0.1-1.5$ & 0.14 & {$[38]$} \\
East China Sea, China & 37 & 2.7 & 8.8 & {$[39]$} \\
Fujian and Guangdong coasts, China & 31.5 & 0.096 & 0.30 & {$[22]$} \\
Kaohsiung Harbor, Taiwan & 1072 & 2.86 & 0.42 & This study \\
\hline
\end{tabular}

\subsection{Correlation of Sediment Characteristics and Total Mercury and Methylmercury}

The sediment characteristics (such as grain size, TOC, $\mathrm{pH}$, and ORP) play an important role in the distributions of $\mathrm{T}-\mathrm{Hg}$ and $\mathrm{MeHg}$ in the sediments, the correlation between the two is proposed above $[12,15,40,41]$. Table 5 lists the Pearson correlation matrix for the sediment characteristics, $\mathrm{T}-\mathrm{Hg}, \mathrm{MeHg}$, and $\mathrm{MeHg}$ ratio. The $\mathrm{T}-\mathrm{Hg}$ concentration in the sediments has no relation to grain size $(p>0.05, r=-0.329-0.274)$ but was significantly and positively correlated to the TOC content $(p<0.05, \mathrm{r}=0.500)$, indicating that the mechanism for sediment adsorption of $\mathrm{Hg}$ was dominantly determined by the chemical adsorption, not the physical surface adsorption [42]. A significantly negative relation was exhibited for the T-Hg concentration with $\mathrm{pH}(p<0.05, \mathrm{r}=-0.510)$ and ORP $(p<0.05, \mathrm{r}=-0.553)$ in the sediments. It could be inferred that $\mathrm{Hg}$ and organic pollution in the sediments of Kaohsiung Harbor were mainly contributed from the riverine freshwater, accumulated in the estuary, and gradually spread to the harbor area. This may be the reason for the negative correlation between the T-Hg concentration in the sediment and the $\mathrm{pH}$ and ORP. The MeHg concentration in the sediments was negatively related with TOC $(p<0.01, \mathrm{r}=0.653), \mathrm{pH}(p<0.05, \mathrm{r}=-0.511)$, and ORP $(p<0.01, \mathrm{r}=-0.711)$. TOC content in the sediment is one of the important factors affecting the $\mathrm{Hg}$ methylation process [2]. The organic matter-rich sediment generally contains relatively higher $\mathrm{MeHg}$ level, because the dissolved organic matters (i.e., electron donor) enhance the activity of microorganism that promotes the $\mathrm{Hg}$ methylation process [2,43].

In addition, the sediments with high TOC content generally had relatively lower $\mathrm{pH}$ and ORP value due to the microbial oxidative decomposition. The lower $\mathrm{pH}$ may increase the solubility and mobility of $\mathrm{Hg}$ and the sediments under anaerobic state (i.e., low ORP), which is favorable to microbial Hg methylation $[2,44]$. Therefore, TOC content in the sediments both directly and indirectly influences 
the formation of $\mathrm{MeHg}$. A significantly linear relationship between $\mathrm{T}-\mathrm{Hg}$ and $\mathrm{MeHg}$ concentrations $(p<0.01, r=0.889)$ suggests that the sediments with the high T-Hg content could provide the relatively more inorganic $\mathrm{Hg}$ (II) (i.e., bioavailable $\mathrm{Hg}$ ) for microbial methylation that results in increasing $\mathrm{MeHg}$ concentration with increasing T-Hg $[12,23,24]$.

Table 5. Pearson correlation matrix for the characteristics, $\mathrm{T}-\mathrm{Hg}, \mathrm{MeHg}$, and $\mathrm{MeHg}$ ratio in the sediments of Kaohsiung Harbor.

\begin{tabular}{ccccccccc}
\hline Item & Clay & Silt & Sand & TOC & pH & ORP & T-Hg & MeHg \\
\hline Silt & $0.939^{\mathrm{a}}$ & & & & & & & \\
Sand & $-0.949^{\mathrm{a}}$ & $-1.000^{\mathrm{a}}$ & & & & & & \\
TOC & -0.140 & -0.032 & 0.017 & & & & & \\
pH & 0.000 & -0.198 & 0.181 & $-0.571^{\mathrm{a}}$ & & & & \\
ORP & 0.159 & 0.077 & -0.085 & $-0.828^{\mathrm{a}}$ & $0.515^{\mathrm{b}}$ & & & \\
T-Hg & -0.329 & -0.267 & 0.274 & $0.500^{\mathrm{b}}$ & $-0.510^{\mathrm{b}}$ & $-0.553^{\mathrm{b}}$ & & \\
$\mathrm{MeHg}$ & -0.441 & -0.392 & 0.398 & $0.653^{\mathrm{a}}$ & $-0.511^{\mathrm{b}}$ & $-0.711^{\mathrm{a}}$ & $0.889^{\mathrm{a}}$ & \\
MeHg ratio & -0.199 & -0.199 & 0.220 & 0.177 & -0.129 & -0.154 & -0.171 & 0.172 \\
\hline \multicolumn{7}{c}{${ }^{\mathrm{a}}$ Correlation is significant at the 0.01 level (2-tailed). ${ }^{\mathrm{b}}$ Correlation is significant at the 0.05 level (2-tailed). }
\end{tabular}

No significant correlation was found between $\mathrm{MeHg}$ ratio and all other measured parameters, indicating that it could have the other critical factor affecting the $\mathrm{MeHg}$ ratio. The $\mathrm{MeHg}$ ratio is mainly determined by the activities of microorganism relatively for methylation and demethylation and the proportion of bioavailable inorganic $\mathrm{Hg}$ in the sediments. However, determining the net rate of methylation and demethylation processes includes a network of biogeochemical reactions and environmental conditions [26,45]. The main factors affecting the $\mathrm{Hg}$ methylation are numerous and complex, including microorganisms, sulfide, organic matter, iron, selenium, $\mathrm{pH}$, temperature, drying and wetting cycles, the age of $\mathrm{Hg}$, redox stations, and salinity. Therefore, the main factors to determine the $\mathrm{MeHg}$ ratio may be an unmeasured item from the above factors or a combination of all the above factors $[2,26]$.

\section{Conclusions}

Analysis for T-Hg and MeHg in the sediments of harbor and estuary in Kaohsiung Harbor (Taiwan) was carried out. The distributions, levels of $\mathrm{T}-\mathrm{Hg}$ and $\mathrm{MeHg}$, and the correlation analysis with sediments characteristics were also evaluated. The T-Hg and $\mathrm{MeHg}$ concentrations in the sediments were between 149 and $9035 \mu \mathrm{g} / \mathrm{kg}$ as well as $<0.31$ and $17.7 \mu \mathrm{g} / \mathrm{kg}$, respectively. Relatively higher concentrations of T-Hg and MeHg were found in the sediments of the estuaries in Kaohsiung Harbor. The results suggested that $\mathrm{Hg}$ in the study area likely originated from the river catchments. The $\mathrm{MeHg}$ level was $<0.01$ to $2.66 \%$ of the T-Hg concentration in the sediments. There is a positive correlation between $\mathrm{MeHg}$ and T-Hg concentrations and TOC content, but a negative correlation was observed between $\mathrm{pH}$ and ORP values with the $\mathrm{MeHg}$ concentrations in the sediments of the studied area. This study can be useful for the MeHg monitoring in the sediments of the harbor and for the design of future strategies in environmental protection of the harbor environments, with a special focus on the area at the estuary.

Author Contributions: Conceptualization, C.-F.C. and C.-D.D.; Methodology, C.-F.C.; Formal Analysis, C.-F.C.; Investigation, G.-T.L.; Resources, G.-T.L. and C.-W.C.; Writing-Original Draft Preparation, C.-F.C. and Y.-R.J.; Writing-Review \& Editing, C.-F.C. and Y.-R.J.; Visualization, C.-F.C.; Supervision, C.-D.D. and C.-W.C.; Project Administration, C.-W.C.; Funding Acquisition, C.-D.D.

Funding: This research was supported by the Taiwan International Ports Corporation (TIPC), Taiwan.

Acknowledgments: The authors thank C.P. Huang of University of Delaware, US for his support throughout this study and proof read of the manuscript.

Conflicts of Interest: The authors declare no conflicts of interest. 


\section{References}

1. Zhang, L.; Wong, M.H. Environmental mercury contamination in China: Sources and impacts. Environ. Int. 2007, 33, 108-121. [CrossRef] [PubMed]

2. Bigham, G.N.; Murray, K.J.; Masue-Slowey, Y.; Henry, E.A. Biogeochemical controls on methylmercury in soils and sediments: Implications for site management. Integr. Environ. Assess. Manag. 2017, 13, 249-263. [CrossRef] [PubMed]

3. Strickman, R.J.; Mitchell, C.P.J. Methylmercury production and accumulation in urban stormwater ponds and habitat wetlands. Environ. Pollut. 2017, 221, 326-334. [CrossRef] [PubMed]

4. Gilmour, C.C.; Podar, M.; Bullock, A.L.; Graham, A.M.; Brown, S.D.; Somenahally, A.C.; Johs, A.; Hurt, R.A.; Bailey, K.L.; Elias, D.A. Mercury methylation by novel microorganisms from new environments. Environ. Sci. Technol. 2013, 47, 11810-11820. [CrossRef] [PubMed]

5. Kerin, E.J.; Gilmour, C.C.; Roden, E.; Suzuki, M.T.; Coates, J.D.; Mason, R.P. Mercury methylation by dissimilatory iron-reducing bacteria. Appl. Environ. Microbiol. 2006, 72, 7919-7921. [CrossRef] [PubMed]

6. Hamelin, S.; Amyot, M.; Barkay, T.; Wang, Y.P.; Planas, D. Methanogens: Principal methylators of mercury in lake periphyton. Environ. Sci. Technol. 2011, 45, 7693-7700. [CrossRef] [PubMed]

7. Yu, R.Q.; Reinfelder, J.R.; Hines, M.E.; Barkay, T. Mercury methylation by the methanogen Methanospirillum hungatei. Appl. Environ. Microbiol. 2013, 79, 6325-6330. [CrossRef] [PubMed]

8. Schartup, A.T.; Mason, R.P.; Balcom, P.H.; Hollweg, T.A.; Chen, C.Y. Methylmercury production in estuarine sediments: Role of organic matter. Environ. Sci. Technol. 2013, 47, 695-700. [CrossRef] [PubMed]

9. Carrasco, L.; Vassileva, E. Determination of methylmercury in marine sediment samples: Method validation and occurrence data. Anal. Chim. Acta 2015, 853, 167-178. [CrossRef] [PubMed]

10. Hsu-Kim, H.; Kucharzyk, K.H.; Zhang, T.; Deshusses, M.A. Mechanisms regulating mercury bioavailability for methylating microorganisms in the aquatic environment: A critical review. Environ. Sci. Technol. 2013, 47, 2441-2456. [CrossRef] [PubMed]

11. Kannan, K.; Smith, R.G., Jr.; Lee, R.F.; Windom, H.L.; Heitmuller, P.T.; Macauley, J.M.; Summers, J.K. Distribution of total mercury and methylmercury in water sediment and fish from south Florida estuaries. Arch. Environ. Contam. Toxicol. 1998, 34, 109-118. [CrossRef] [PubMed]

12. Haris, H.; Aris, A.Z.; Mokhtar, M. Mercury and methylmercury distribution in the intertidal surface sediment of a heavily anthrophogenically impacted saltwater-mangrove-sediment interplay zone. Chemosphere 2017, 166, 323-333. [CrossRef] [PubMed]

13. Chen, S.S.; Chou, S.S.; Hwang, D.F. Determination of methyl- and inorganic mercury in fish using focused microwave digestion followed by $\mathrm{Cu}++$ addition, sodium tetraethylborate derivatization, n-Heptane extraction, and gas chromatography mass spectrometry. J. Food Drug. Anal. 2004, 12, 175-182.

14. Chen, C.Y.; Ward, D.M.; Williams, J.J.; Fisher, N.S. Metal bioaccumulation by estuarine food webs in New England, USA. J. Mar. Sci. Eng. 2016, 4, 41. [CrossRef] [PubMed]

15. Dong, C.D.; Chen, C.W.; Chen, C.F. Distribution, enrichment, accumulation and potential ecological risks of mercury in the sediments of Kaohsiung Harbor, Taiwan. Chem. Ecol. 2013, 29, 693-708. [CrossRef]

16. Loring, D.H.; Rantala, R.T.T. Manual for the geochemical analyses of marine sediments and suspended particulate matter. Earth-Sci. Rev. 1992, 32, 235-283. [CrossRef]

17. Chen, C.W.; Chen, C.F.; Dong, C.D.; Tu, Y.T. Composition and source apportionment of PAHs in sediments at river mouths and channel in Kaohsiung Harbor, Taiwan. J. Environ. Monit. 2012, 14, 105-115. [CrossRef] [PubMed]

18. National Institute of Environmental Analysis. Soil Acid-Base Value $(\mathrm{pH})$ Determination Method-Electrode Method, NIEA S410.62C, Taiwan. 2009. Available online: http:/ / www.taiwanlab.com.tw/protocol/show. asp?id=1407 (accessed on 15 August 2018).

19. National Institute of Environmental Analysis. Sediment Sampling Methods, NIEA S104.32B, Taiwan. 2016. Available online: http:/ / www.rootlaw.com.tw/LawContent.aspx?LawID=A040300081076900-1050104 (accessed on 15 August 2018).

20. Long, E.R.; MacDonald, D.D.; Smith, S.L.; Calder, F.D. Incidence of adverse biological effects within ranges of chemical concentrations in marine and estuarine sediments. Environ. Manag. 1995, 19, 81-87. [CrossRef] 
21. Chen, C.F.; Dong, C.D.; Chen, C.W. Metal speciation and contamination in dredged harbor sediments from Kaohsiung Harbor, Taiwan. Soil. Sediment. Contam. 2013, 22, 546-561. [CrossRef]

22. Zhang, Y.; Huo, Y.; Liu, X.; Kuang, W.; Yuang, D.; Ji, W. Environmental impact factors and mercury speciation in the sediment along Fujian and eastern Guangdong coasts. Acta Oceanol. Sin. 2013, 32, 76-80. [CrossRef]

23. Bełdowski, J.; Miotk, M.; Bełdowska, M.; Pempkowiak, J. Total, methyl and organic mercury in sediments of the Southern Baltic Sea. Mar. Pollut. Bull. 2014, 87, 388-395. [CrossRef] [PubMed]

24. Matsuyama, A.; Yano, S.; Hisano, A.; Kindaichi, M.; Sonoda, I.; Tada, A.; Akagi, H. Distribution and characteristics of methylmercury in surface sediment in Minamata Bay. Mar. Pollut. Bull. 2016, 109, 378-385. [CrossRef] [PubMed]

25. Mason, R.P.; Lawrence, A.L. Concentration, distribution, and bioavailability of mercury and methylmercury in sediments of Baltimore Harbor and Chesapeake Bay Maryland, USA. Environ. Toxicol. Chem. 1999, 18, 2438-2447. [CrossRef]

26. Ullrich, S.M.; Tanton, T.W.; Abdrashitova, S.A. Mercury in the aquatic environment: A review of factors affecting methylation. Crit. Rev. Environ. Sci. Technol. 2001, 31, 241-293. [CrossRef]

27. Heyes, A.; Miller, C.; Mason, R.P. Mercury and methylmercury in Hudson River sediment impact of tidal resuspension on partitioning and methylation. Mar. Chem. 2004, 90, 75-89. [CrossRef]

28. Conaway, C.H.; Squire, S.; Mason, R.P.; Flegal, A.R. Mercury speciation in the San Francisco Bay estuary. Mar. Chem. 2003, 80, 199-225. [CrossRef]

29. Taylor, D.L.; Linehan, J.C.; Murray, D.W.; Prell, W.L. Indicators of sediment and biotic mercury contamination in a southern New England estuary. Mar. Pollut. Bull. 2012, 64, 807-819. [CrossRef] [PubMed]

30. Covelli, S.; Faganeli, J.; Horvat, M.; Brambati, A. Mercury contamination of coastal sediments as the result of long-term cinnabar mining activity (Gulf of Trieste, northern Adriatic Sea). Appl. Geochem. 2001, 16, 541-558. [CrossRef]

31. Spada, L.; Annicchiarico, C.; Cardellicchio, N.; Giandomenico, S.; Di Leo, A. Mercury and methylmercury concentrations in Mediterranean seafood and surface sediments, intake evaluation and risk for consumers. Int. J. Hyg. Environ. Health. 2012, 215, 418-426. [CrossRef] [PubMed]

32. Kannan, K.; Falandysz, J. Speciation and concentrations of mercury in certain coastal marine sediments. Water Air Soil Pollut. 1998, 103, 129-136. [CrossRef]

33. Ogrinc, N.; Monperrus, M.; Kotnika, J.; Fajona, V.; Vidimovab, K.; Amouroux, D.; Kocmana, D.; Tessier, E.; Žižek, S.; Horvat, M. Distribution of mercury and methylmercury in deep-sea surficial sediments of Mediterranean Sea. Mar. Chem. 2007, 107, 31-48. [CrossRef]

34. Landaluze, J.S.; De Diego, A.; Raposo, J.C.; Madariaga, J.M. Methylmercury determination in sediments and fish tissues from the Nerbioi-Ibaizabal estuary (Basque Country, Spain). Anal. Chim. Acta 2004, 508, 107-117. [CrossRef]

35. Agah, H.; Elskens, M.; Fatemi, S.M.R.; Owfi, F.; Baeyens, W.; Leermakers, M. Mercury speciation in the Persian Gulf sediments. Environ. Monit. Assess. 2009, 157, 363-373. [CrossRef] [PubMed]

36. Agah, H.; Owfi, F.; Sharif Fazeli, M.; Fatemi, S.M.R.; Savari, A. Determining mercury and methylmercury in sediments of the northern parts of the Persian Gulf. J. Oceanogr. 2010, 1, 7-13.

37. Abi-Ghanem, C.; Nakhlé, K.; Khalaf, G.; Cossa, D. Mercury distribution and methylmercury mobility in the sediments of three sites on the Lebanese coast, eastern Mediterranean. Arch. Environ. Contam. Toxicol. 2011, 60, 394-405. [CrossRef] [PubMed]

38. Shi, J.B.; Ip, C.C.M.; Tang, C.W.Y.; Zhang, G.; Wu, R.S.S.; Li, X.D. Spatial and temporal variations of mercury in sediments from Victoria Harbour, Hong Kong. Mar. Pollut. Bull. 2007, 54, 480-485. [CrossRef] [PubMed]

39. Shi, J.B.; Liang, L.N.; Yuan, C.G.; He, B.; Jiang, G.B. Methylmercury and total mercury in sediment collected from the East China Sea. Bull. Environ. Contam. Toxicol. 2005, 74, 980-987. [CrossRef] [PubMed]

40. Hammerschmidt, C.R.; Fitzgerald, W.F. Methylmercury cycling in sediments on the continental shelf of southern New England. Geochim. Cosmochim. Acta 2006, 70, 918-930. [CrossRef]

41. Randall, P.M.; Chattopadhyay, S. Mercury contaminated sediment sites-an evaluation of remedial options. Environ. Res. 2013, 125, 131-149. [CrossRef] [PubMed]

42. Chen, C.W.; Kao, C.M.; Chen, C.F.; Dong, C.D. Distribution and accumulation of heavy metals in the sediments of Kaohsiung Harbor, Taiwan. Chemosphere 2007, 66, 1431-1440. [CrossRef] [PubMed] 
43. Meng, B.; Feng, X.; Qiu, G.; Li, Z.; Yao, H.; Shang, L.; Yan, H. The impacts of organic matter on the distribution and methylation of mercury in a hydroelectric reservoir in Wujiang River, Southwest China. Environ. Toxicol. Chem. 2016, 35, 191-199. [CrossRef] [PubMed]

44. Watras, C.J.; Back, R.C.; Halvorsen, S.; Hudson, R.J.M.; Morrison, K.A.; Wente, S.P. Bioaccumulation of mercury in pelagic freshwater food webs. Sci. Total. Environ. 1998, 219, 183-208. [CrossRef]

45. Fleck, J.A.; Marvin-DiPasquale, M.; Eagles-Smith, C.A.; Ackerman, J.T.; Lutz, M.A.; Tate, M.; Alpers, C.N.; Hall, B.D.; Krabbenhoft, D.P.; Eckley, C.S. Mercury and methylmercury in aquatic sediment across western North America. Sci. Total. Environ. 2016, 568, 727-738. [CrossRef] [PubMed]

(C) 2018 by the authors. Licensee MDPI, Basel, Switzerland. This article is an open access article distributed under the terms and conditions of the Creative Commons Attribution (CC BY) license (http:/ / creativecommons.org/licenses/by/4.0/). 